Foss. Rec., 22, 45-49, 2019

https://doi.org/10.5194/fr-22-45-2019

(C) Author(s) 2019. This work is distributed under

the Creative Commons Attribution 4.0 License.

\title{
Groehnius, a new genus of Eugnomini (Coleoptera: Curculionidae) from Eocene Baltic amber
}

\author{
Andris Bukejs ${ }^{1}$ and Andrei A. Legalov ${ }^{2,3}$ \\ ${ }^{1}$ Institute of Life Sciences and Technologies, Daugavpils University, Vienības 13, Daugavpils, 5401, Latvia \\ ${ }^{2}$ Institute of Systematics and Ecology of Animals, Siberian Branch, Russian Academy of Sciences, \\ Frunze Street 11, Novosibirsk 630091, Russia \\ ${ }^{3}$ Biological Institute, Tomsk State University, Lenina Prospekt 36, Tomsk 634050, Russia
}

Correspondence: Andrei A. Legalov (fossilweevils@gmail.com)

Received: 13 June 2019 - Revised: 25 July 2019 - Accepted: 26 July 2019 - Published: 15 August 2019

\begin{abstract}
A new weevil, Groehnius electrum Bukejs and Legalov, gen. et sp. nov. (Coleoptera: Curculionidae: Curculioninae), is described from Eocene Baltic amber. This new genus is similar to the genus Archaeoeugnomus Legalov, 2016 from Baltic amber but differs in the femora without ventral teeth, and the scape not reaching the anterior margin of the eye. It is the second record of the tribe Eugnomini in the Eocene.
\end{abstract}

\section{Introduction}

The subfamily Curculioninae is a morphologically very diverse group and includes more than 30 tribes in the Holocene fauna (Caldara et al., 2014). The oldest representative of the tribe Curculionini from this subfamily is known from the Paleocene of Menat (Legalov et al., 2017). The Curculioninae from fossil resin usually are known by type specimens only (Legalov, 2015): the tribes Acalyptini, Curculionini, Ellescini, Eugnomini, Rhamphini and Tychiini are known from the lowermost Eocene Oise (Legalov et al., 2019a) and Upper Eocene Baltic and Rovno ambers (Kuśka, 1996; Rheinheimer, 2007; Legalov, 2016a, b; Legalov et al., 2019b); and the tribes Anthonomini, Derelomini and Tychiini are found in the Early Miocene Dominican and Mexican ambers (Poinar Jr. and Legalov, 2015; Legalov and Poinar, 2016; Legalov, 2019). In the current paper, a new genus and new species belonging to the tribe Eugnomini are described and illustrated from Baltic amber.

\section{Material and methods}

The material examined comes from the collection of Carsten Gröhn (Glinde, Germany) and deposited in the Center of Natural History (Centrum für Naturkunde - CeNak; formerly the Geological-Paleontological Institute and Museum - Das Geologisch-Paläontologische Museum, GPIH) of the University of Hamburg, Germany. The amber piece was handpolished to allow an improved view of the included specimen and was not subject to any additional fixation.

The material was studied using a Nikon SMZ ${ }^{\circledR} 745$ T stereomicroscope. Photographs were taken using a Canon $70 \mathrm{D}^{\circledR}$ camera with a macro lens (Canon M-PE $65 \mathrm{~mm}$ ). Extended depth of field was achieved at high magnifications by combining multiple images from a range of focal planes using Helicon Focus ${ }^{\circledR}$ v. 6.0.18 software. Measurements were taken using an ocular micrometer (expressed in millimetres).

The morphological terminology used in this paper follows Lawrence et al. (2010).

\section{Systematic paleontology}

Family Curculionidae Latreille, 1802

Subfamily Curculioninae Latreille, 1802

Tribe Eugnomini Lacordaire, 1863

Genus Groehnius gen. nov. urn:1sid:zoobank.org:act:32C41A65-20E9-40FEBE86-0281037ЕBC74 


\section{Type species}

Groehnius electrum sp. nov., herein designated.

\section{Etymology}

The generic name is dedicated to Carsten Gröhn (Glinde, Germany), who provided the specimen for examination. Gender masculine.

\section{Diagnosis}

Body is elongated, densely covered with short recumbent setae; head prognathous; rostrum longer than pronotum, with geniculate antennae inserted in apical one-third; mandibles simple; antennal scrobes lateral, obliquely directed toward the rostrum base; eyes very large, convex; scape not reaching anterior margin of eye; pronotum distinctly narrower than elytra with constriction at anterior margin; precoxal portion of prothorax elongate; elytra elongate and with regular striae; abdominal ventrites 1 and 2 quite long, 3 and 4 short; femora and tibia subequal in length; femora swollen medially, without ventral teeth; tibiae without mucro or uncus, almost straight; claws free, simple, branched.

\section{Comparison}

The new genus is similar to the genus Archaeoeugnomus Legalov, 2016 from Baltic amber but differs in the femora without ventral teeth, and scape not reaching the anterior margin of the eye.

\section{Remarks}

Groehnius gen. nov. belongs to the tribe Eugnomini within Curculioninae based on the oblique antennal scrobes directed toward the rostrum base, antennae inserted close to the apex, very large eyes, and the tarsal claws free and branched.

Groehnius electrum sp. nov.

urn:lsid:zoobank.org:act:174CA693-74E9-48ACA014-52A2C20A70BD

Figs. 1-2.

\section{Etymology}

The species name is a noun in apposition and is one of the Latin words for amber-electrum.

\section{Holotype}

Holotype: "coll. Gröhn 8607", deposited at the Center of Natural History (Centrum für Naturkunde - CeNak; formerly the Geological-Paleontological Institute and Museum - Das Geologisch-Paläontologische Museum, GPIH) of the University of Hamburg, Germany; adult, sex unknown. Complete beetle included in transparent yellow piece of amber with dimensions $33 \mathrm{~mm} \times 18 \mathrm{~mm} \times 4 \mathrm{~mm}$. Ventral side of specimen almost completely obscured by "milky cover". Syninclusions: one undetermined Brachycera (Diptera) specimen, few stellate Fagaceae trichomes, and some gas vesicles.

\section{Type strata}

Baltic amber, mid-Eocene to Upper Eocene.

\section{Type locality}

Baltic Sea coast, Yantarny settlement (formerly Palmnicken), Kaliningrad region, Russia.

\section{Description}

Measurements: body length (without rostrum) $3.5 \mathrm{~mm}$, rostrum length about $1.1 \mathrm{~mm}$; head length $0.3 \mathrm{~mm}$, head width (including eyes) $0.55 \mathrm{~mm}$; pronotum length $0.88 \mathrm{~mm}$, pronotum maximum width $0.95 \mathrm{~mm}$; elytra length $2.4 \mathrm{~mm}$, elytra maximum width $1.45 \mathrm{~mm}$.

Body: elongated, slightly convex; unicolorous black (as preserved). Pubescence: body moderately densely covered with short, fine recumbent setae dorsally and ventrally; pronotum additionally with sparse, longer recumbent setae, with long, erect seta near each angle, and with short curved hair-like scales at lateral sides; elytra additionally with sparse, longer erect setae.

Head: prognathous, apparently without distinct punctation; forehead slightly convex. Rostrum long, about 1.4 times as long as pronotum, moderately curved downward, slightly dilated anteriad; antennal scrobes lateral, slightly obliquely directed toward the rostrum base; rostrum about 5.5 times as long as wide apically, 7.3 times as long as wide medially and basally; apparently with dense, fine punctation. Compound eyes very large, suboval, slightly convex. Temples about 0.3 times as long as transverse diameter of one eye. Antennae with 11 antennomeres, clavate, with distinct three-segmented club; sparsely covered with short, semierect setae; inserted in apical one-third of rostrum; moderately long, reaching nearly basal one-third of pronotum; scape elongate, not reaching anterior margin of eye, distinctly dilated apically, about 2.7 times as long as antennomere 2; funicle (antennomeres 2-8) slender, 2.9 times as long as club; antennomere 2 elongate, subcylindrical, as wide as scape apically and about 3 times as wide as antennomere 3; antennomeres 3-4 elongate, cylindrical, subequal in length and wide; antennomeres 5-6 slightly elongate, 2.0-1.5 times as long as wide; antennomeres 7-8 quadratic, about as long as wide; antennal club rather wide and long, 1.9 times as long as wide, antennomeres 8-9 transverse, 1.2-1.4 times as wide as long, antennomere 8 about 2.3 times as wide as antennomere 7 , antennomere 11 tapered apically.

Pronotum: slightly transverse, about 1.2 times as wide as long, distinctly narrower than anterior elytral margin, with 


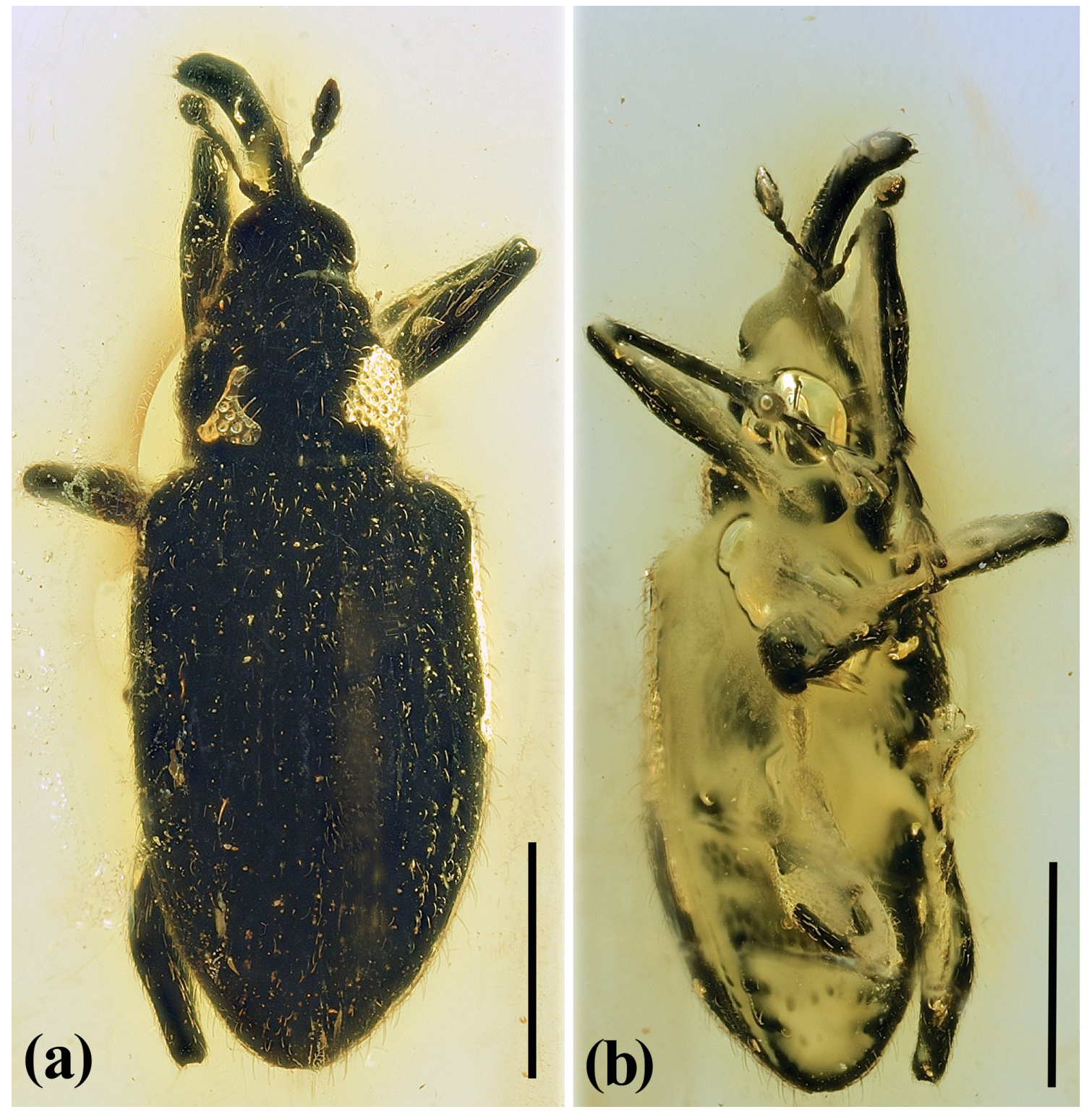

Figure 1. Groehnius electrum gen. et sp. nov., holotype: (a) habitus, dorsal view; (b) habitus, ventrolateral view. Scale bar $=1 \mathrm{~mm}$.

constriction at anterior margin, widest medially, distinctly narrowed anteriad and slightly narrowed posteriad; disc slightly convex; densely covered with large and deep punctation, distance between punctures distinctly smaller than diameter of one puncture. Lateral margins widely rounded in basal three-fourths and straight in anterior one-fourth; anterior margin almost straight; posterior margin slightly rounded. Precoxal portion of prothorax elongate, postcoxal portion short.

Elytra: elongate, 1.7 times as long as wide, about 3.0 times as long as pronotum, with almost parallel lateral sides in anterior two-thirds and gradually narrowing in posterior onethird. Elytral punctation apparently dense and large, punc- tures arranged in regular striae; intervals distinctly convex, wider than striae. Humeri developed, prominent.

Abdomen: with five visible ventrites, slightly convex; ventrites 3 and 4 short, equal in length, ventral plate 3 distinctly narrower than ventral plate 2 , ventral plate 4 about 0.7 times as long as ventral plate 5 . Relative length ratios of ventrites $1-5$ equal to $15-15-7-7-10$.

Legs: long, slender, covered with sparse, recumbent setae and fine punctures; femora and tibia subequal in length. Femora spindle-shaped, slightly swollen medially, without teeth ventrally. Tibiae elongate, without mucro or uncus, almost straight, protibia about 9.1 times as long as wide medially. Tarsi elongate, about 0.5 times as long as tibia, tarsomere 1 elongate, slightly dilated apically, tarsomere 


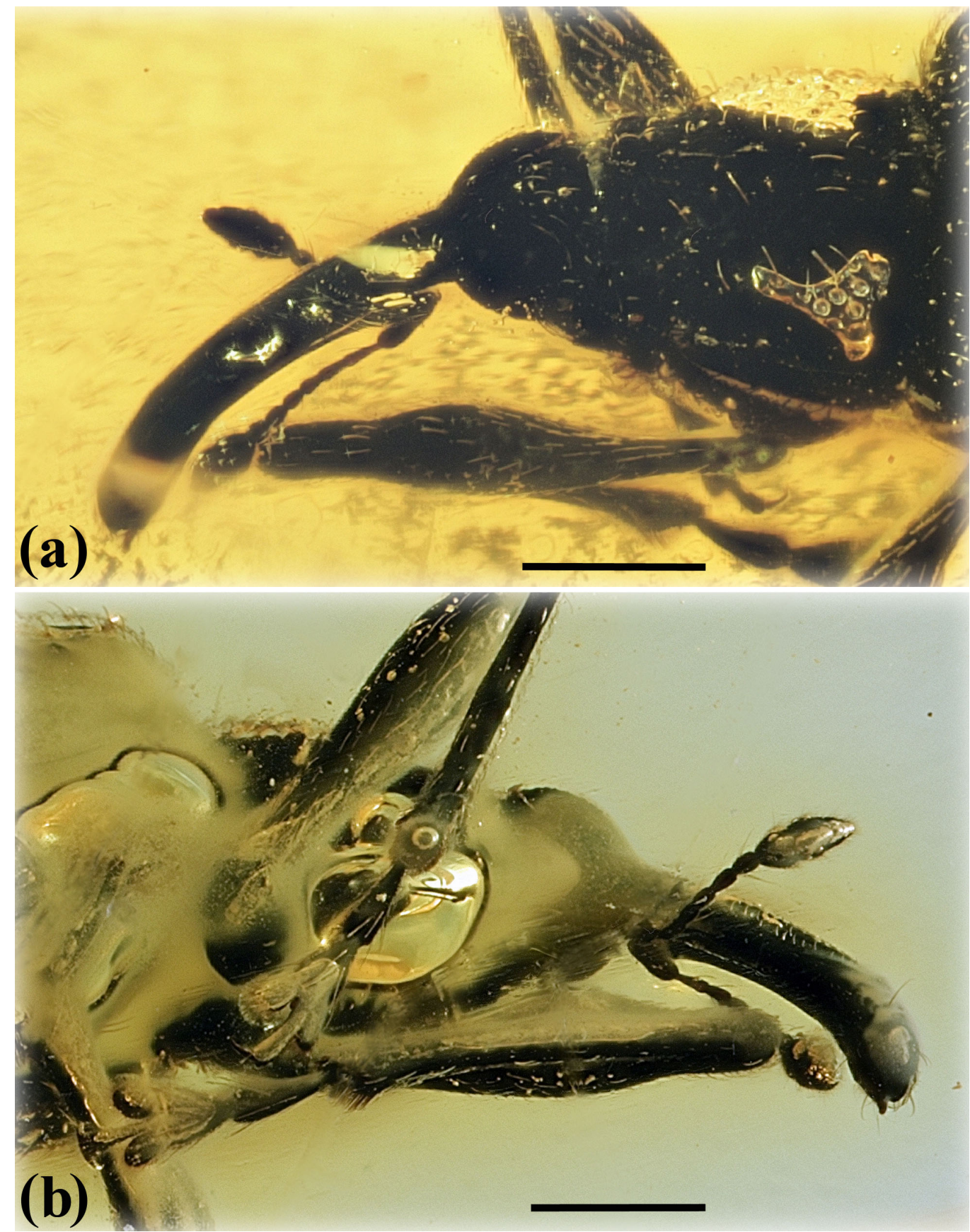

Figure 2. Groehnius electrum gen. et sp. nov., holotype: (a) details of fore-body, dorsal view; (b) details of fore-body, ventrolateral view. Scale bar $=0.5 \mathrm{~mm}$.

2 shorter than tarsomere 1 , distinctly dilated apically, tarsomere 3 bilobed, strongly dilated apically, tarsomere 5 narrow; metatarsomere 1 about 3.4 times as long as wide, metatarsomere 2 about 1.3 times as long as wide, 0.5 times as long as metatarsomere 1. Claws free, simple (without teeth basally), branched.

\section{Discussion}

The tribe Eugnomini is not rich in species and currently distributed mainly in Australia, New Zealand and New Caledonia; it also occurs in Central and South America (Caldara et al., 2014). Fossil taxa of this tribe are known from the Eocene Baltic amber only and represented by two genera with few species: Archaeoeugnomus balticus Legalov, 2016 (there are 
also some undescribed species belonging to Archaeoeugnomus) and Groehnius electrum gen. et sp. nov. The Eocene genera are more similar to American genera in the simple tibial apex than to the genera from the Australian region. The trophic association of new fossil taxon cannot be assumed because of the wide spectrum of the host plants of extant Eugnomini (Caldara et al., 2014).

Data availability. All material included in the paper is accessible in the collection of Carsten Gröhn (Glinde, Germany) and is deposited in the Center of Natural History (CeNak) (formerly GeologicalPaleontological Institute and Museum, GPIH) of the University of Hamburg, Germany, and all data are included in the description.

Author contributions. AB and AAL prepared the paper and contributed to the editing.

Competing interests. The authors declare that they have no conflict of interest.

Acknowledgements. The authors are sincerely grateful to Carsten Gröhn (Glinde, Germany) for the loan of interesting fossil material and to Jonas Damzen (Vilnius, Lithuania) for permission to use his photographs. The authors thank Vitalii I. Alekseev (Shirshov Institute of Oceanology, Russian Academy of Sciences, Moscow, Russia) and Alexander G. Kirejtshuk (Zoological Institute of the Russian Academy of Sciences, St. Petersburg, Russia) for their valuable suggestions that improved the manuscript.

Financial support. The study was partially supported by the Russian Foundation for Basic Research (project nos. 18-04-00243-a and 19-04-00465-a) and the Federal Fundamental Scientific Research Program for 2013-2020 (project no. AAAA-A16-1161214101217).

Review statement. This paper was edited by Florian Witzmann and reviewed by Alexander Kirejtshuk and Vitalii Alekseev.

\section{References}

Caldara, R., Franz, N. M., and Oberprieler, R. G.: 3.7.10 Curculioninae Latreille, 1802. Handbook of Zoology. Arthropoda: Insecta. Tb. 40: Coleoptera (Beetles), Vol. 3: Morphology and systematics (Phytophaga), Walter de Gruyter, Berlin, Germany, 589-628, 2014.

Kuśka, A.: New beetle species (Coleoptera, Cantharidae, Curculionidae) from the Baltic amber, Prace Muz. Ziemi, 44, 13-23, 1996.

Lawrence, J. F., Beutel, R. G., Leschen, R. A. B., and Ślipiński, S. A.: Chapter 2. Glossary of Morphological Terms. Handbook of Zoology. Arthropoda: Insecta. Tb. 40: Coleoptera (Beetles), Vol. 2: Morphology and systematics (Phytophaga partym), Walter de Gruyter, Berlin, Germany, 9-20, 2010.

Legalov, A. A.: Fossil weevils (Coleoptera, Obrienioidea, Curculionoidea) from Mesozoic and Cainozoic, Paleontol. J., 49, 1442-1513, https://doi.org/10.1134/S0031030115130067, 2015.

Legalov, A. A.: Two new genera and four new species of fossil weevils (Coleoptera: Curculionoidea) in Baltic amber, Entomol. Fennica, 27, 57-69, 2016a.

Legalov, A. A.: New weevils (Curculionidae) in Baltic amber, Paleontol. J., 50, 970-985, https://doi.org/10.1134/S0031030116090057, 2016b.

Legalov, A. A.: New species of weevils (Coleoptera, Curculionidae) in Dominican amber, Paleontol. J., 53, in press, 2019.

Legalov, A. A. and Poinar Jr., G.: A new species of the genus Anthonomus Germar, 1817 (Coleoptera: Curculionidae) in Mexican amber, Paleontol. J., 50, 986-990, https://doi.org/10.1134/S0031030116090069, 2016.

Legalov, A. A., Nel, A., and Kirejtshuk, A. G.: New and little known weevils (Coleoptera: Curculionoidea) from the $\mathrm{Pa}-$ leocene of Menat (France), C. R. Palevol., 16, 248-256, https://doi.org/10.1016/j.crpv.2016.10.007, 2017.

Legalov, A. A., Kirejtshuk, A. G., and Nel, A.: New weevils (Coleoptera, Curculionoidea) from the earlymost Eocene Oise amber, Paleontol. J., 53, 63-85, 2019a.

Legalov, A. A., Nazarenko, V. Y., and Perkovsky, E. E.: New weevils (Coleoptera: Curculionidae) from the Rovno amber, Paleontol. J., 53, in press, 2019b.

Poinar Jr., G. and Legalov, A. A.: New Curculioninae (Coleoptera: Curculionidae) in Dominican amber, Palaeontol. Electron., 18, 1-15, https://doi.org/10.26879/480, 2015.

Rheinheimer, J.: Neue fossile Rüsselkäfer (Coleoptera: Curculionidae) aus dem Eozän des Baltischen Bernsteins und der Grube Messel bei Darmstadt, Staatliches. Mus. Nat., B, 365, 1-24, 2007. 